\title{
MENINGKATKAN HASIL BELAJAR DENGAN MENGGUNAKAN PENERAPAN METODE KOOPERATIF SCRIPT SISWA KELAS IV SD NEGERI 167647 TEBING TINGGI
}

\author{
Benny Hutapea \\ Surel: bhutapea214@gmail.com
}

\begin{abstract}
This study aims to improve student learning outcomes using the application of the cooperative method script fourth grade students of SD Negeri 167647 Tebing Tinggi City. The cooperative script method is one of several methods in the cooperative learning model (Cooperative Learning). This method was proposed by Danserau and friends in 1985. Cooperative learning is a group learning activity to work together to help construct concepts, solve problems or inquiry (Suyatno, 2009: 51). From the results of the learning activities that have been carried out it can be concluded that the application of cooperative script learning methods has a positive impact in increasing students' interest and learning achievement on Indonesian language subjects in Class IV 167677 SD Negeri Tebing Tinggi which is characterized by an increase in student learning completeness in each cycle. The application of the Cooperative Script method makes students more active, accountable for their assignments and delivers news / story ideas about Indonesian language learning material taught by teachers individually or in groups.
\end{abstract}

Keywords: Learning Outcomes, Cooperative Scripts, Indonesian Language

\begin{abstract}
ABSTRAK
Penelitian ini bertujuan untuk meningkatkan hasil belajar siswa dengan menggunakan penerapan metode kooperatif script siswa kelas IV SD Negeri 167647 Kota Tebing Tinggi. Metode cooperative script merupakan salah satu dari beberapa metode yang ada di model pembelajaran kooperatif (Cooperative Learning). Metode ini dikemukakan oleh Danserau dan kawankawan pada tahun 1985. Pembelajaran kooperatif adalah kegiatan pembelajaran dengan cara berkelompok untuk bekerja sama saling membantu mengkonstruksi konsep, menyelesaikan persoalan atau inkuiri (Suyatno, 2009 : 51). Dari hasil kegiatan pembelajaran yang telah dilakukan dapat disimpulkan bahwa penerapan metode pembelajaran cooperative script memiliki dampak positif dalam meningkatkan minat dan prestasi belajar siswa pada mata pelajaran bahasa Indonesia di Kelas IV SD Negeri 167647 kota Tebing Tinggi yang ditandai dengan peningkatan ketuntasan belajar siswa pada setiap siklusnya. Penerapan metode Cooperative Script membuat siswa lebih aktif, mempertanggungjawabkan tugas serta menyampaikan gagasan berita/cerita mengenai materi pelajaran bahasa Indonesia yang diajarkan guru secara individu maupun kelompok.
\end{abstract}

Kata Kunci : Hasil Belajar, Kooperatif Script, Bahasa Indonesia

PENDAHULUAN

Pembelajaran mengarah pada era kemandirian belajar, didukung dengan sarana telekomunikasi yang semakin baik akan lebih mendekatkan ruang, 
menghemat waktu, proses pembelajaran semakin fleksibel bagi semua orang. Proses pembelajaran melibatkan berbagai kegiatan dan tindakan yang perlu dilakukan siswa untuk memperoleh hasil belajar yang baik. Untuk meningkatkan mutu pembelajaran secara khusus diperlukan perubahan dalam kegiatan proses belajar mengajar, karena proses belajar mengajar untuk mata pelajaran Bahasa Indonesia kurang difokuskan pada siswa. Bahasa Indonesia merupakan salah satu bidang studi yang memiliki tujuan membekali siswa untuk mengembangkan bahasa di samping aspek penalaran dan hafalan sehingga pengetahuan dan informasi yang diterima siswa sebatas produk bahasa dan sastra.

$$
\text { Dalam proses belajar }
$$

mengajar, seorang guru harus dapat menyampaikan materi dengan baik dan mengajak siswa untuk mendengarkan, menyajikan media yang dapat dilihat, memberi kesempatan untuk menulis, mengajukan pertanyaan dan tanggapan sehingga terjadi dialog kreatif yang menunjukkan proses belajar mengajar yang interaktif.

Selain menguasai materi seorang guru juga dituntut untuk menguasai strategi-strategi yang penyampaian materi dengan baik, cara guru menciptakan suasana kelas akan berpengaruh terhadap respon siswa dalam proses pembelajaran. Apabila guru berhasil menciptakan suasana yang menyebabkan siswa termotivasi aktif dalam belajar akan memungkinkan terjadi peningkatan belajar. Oleh karena itu, agar siswa dapat mempelajari dan memahami materi pelajaran Bahasa Indonesia lebih bermakna diperlukan strategi pembelajaran yang tepat dan mampu meningkatkan keterampilan siswa dalam memecahkan masalah. Metode Kooperatif Script adalah salah satu bagian dari pembelajaran kooperatif. Model pembelajaran Kooperatif Script adalah model belajar dimana siswa bekerja berpasangan dan bergantian secara lisan mengikhtisarkan, bagian bagian dari materi yang dipelajari. Menurut Schank dan Abelson dalam Hadi (2007:18), mengatakan bahwa metode pembelajaran Kooperatif Script adalah pembelajaran yang mengatur interaksi siswa seperti ilustrasi kehidupan sosial siswa dengan lingkungannya sebagai individu dalam keluarga, kelompok masyarakat yang lebih luas.

Penulis memilih metode ini karena siswa dapat terlibat secara aktif dalam kegiatan proses pembelajaran. Suasana belajar juga tercipta menyenangkan karena model ini dalam pelaksanaannya interaktif. Siswa diharapkan aktif dalam memecahkan masalah dan materi pelajaran yang diterima akan dapat lebih mudah diserap oleh siswa. Metode ini juga dapat membuat siswa memiliki tanggungjawab yang sama dalam kelompoknya. Guru bertindak sebagai fasilitator, motivator dan moderator dengan tetap memberi arahan dan referensi yang relevan 
dengan materi yang diajarkan dalam Bahasa Indonesia.

Adapun tujuan dari penelitian ini adalah untuk meningkatkan minat dan prestasi belajar Bahasa Indonesia siswa Kelas IV SD Negeri 167647 kota Tebing Tinggi melalui pembelajaran Kooperatif Script.

\section{METODE PENELITIAN}

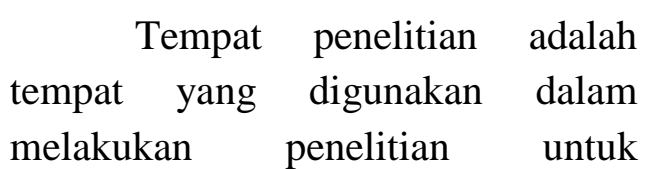
memperoleh data yang diinginkan. Penelitian ini bertempat di SD Negeri 167647 kota Tebing Tinggi. SD Negeri 167647 Tebing Tinggi berada di Jalan Soekarno Hatta, Kelurahan Tambangan Hulu, Kecamatan Padang Hilir, Kota Tebing Tinggi.

Waktu penelitian adalah waktu berlangsungnya penelitian atau saat penelitian ini dilangsungkan.

Subyek penelitian adalah siswa-siswi Kelas IV SD Negeri 167647 kota Tebing Tinggi. Dengan keadaan siswa dalam kelas berjumlah 34 Siswa dimana siswa laki-laki berjumlah 18 orang dan perempuan berjumlah 16 Orang.

Trianggulasi teknik ini digunakan dengan cara menguak data sumber yang sama dengan teknik yang berbeda. Data yang diperoleh dari wawancara lalu dicek dengan observasi dan dokumen (Sugiyono, 2008:12). Triangulasi data adalah penggunaan beragam sumber data dalam suatu penelitian. (Sugiyono, 2008:128).
Penelitian ini dapat dikatakan berhasil dan tidak perlu dilanjutkan kepada siklus berikutnya apabila hasil dari tes siswa yang berjumlah 34 orang telah sesuai dengan KKM yang ditentukan yaitu 65 atau tingkat ketuntasan kelas diatas $85 \%$ dari 34 siswa. Selain itu jika dilihat dari pengelolaan pembelajaran, yaitu persentase pengelolaan pembelajaran yaitu aktivitas guru dan aktivitas siswa diatas $85 \%$.

\section{HASIL PENELITIAN DAN PEMBAHASAN \\ Siklus I}

Pelaksanaan kegiatan belajar mengajar untuk siklus I dilaksanakan pada tanggal 25 Agustus 2017 di Kelas IV dengan jumlah siswa 34 siswa. Setiap siklusnya satu kali pertemuan. Dalam hal ini peneliti bertindak sebagai guru. Adapun proses belajar mengajar mengacu pada rencana pelajaran yang telah dipersiapkan. Pada pengamatan (observasi) dilaksanakan bersamaan dengan pelaksaaan belajar mengajar. Pada akhir proses belajar mengajar siswa diberi soal ulangan harian I dengan tujuan untuk mengetahui tingkat keberhasilan siswa dalam proses belajar mengajar yang telah dilakukan. tampak bahwa aktivitas guru yang paling dominan pada siklus I adalah menugaskan siswa memecahkan masalah dalam kelompok, yaitu 7,5\%. Aktivitas lain yang presentasinya cukup besar adalah meminta siswa menyajikan dan mendiskusikan hasil kegiatan sebesar 7,0 \%. Sedangkan aktivitas siswa yang paling dominan adalah mengerjakan tes yang diberikan guru yaitu 13,5 \%. Aktivitas lain yang presentasinya cukup besar adalah 
menyajikan hasil pelajaran sebesar $9,2 \%$.

Pada siklus I, secara garis besar kegiatan belajar mengajar dengan metode pembelajaran Kooperatif Script dilaksanakan belum dengan baik, peran guru masih cukup dominan untuk memberikan penjelasan dan arahan, karena model tersebut masih dirasakan baru oleh siswa. Siswa masih kurang aktif dalam kegiatan pembelajaran karena belum terbiasa dengan metode pembelajaran Kooperatif Script. dapat dijelaskan bahwa dengan menerapkan metode pembelajaran Kooperatif Script pada materi pelajaran diperoleh nilai rata-rata prestasi belajar siswa adalah 68,5 dan ketuntasan belajar mencapai 67,64\% atau ada 23 siswa dari 34 siswa sudah tuntas belajar. Hasil tersebut menunjukkan bahwa pada siklus pertama secara klasikal siswa belum tuntas belajar, karena siswa yang memperoleh nilai $\geq 65$ hanya sebesar $67,64 \%$ lebih kecil dari persentase ketuntasan yang dikehendaki yaitu sebesar 85\%. Hal ini disebabkan karena siswa banyak yang menganggap sepele dengan mata pelajaran Bahasa Indonesia dan tidak mengulangi pelajaran yang telah dipelajari di rumah. Selain itu, siswa lupa dengan materi pelajaran yang telah diajarkan selama hampir satu semester ini.

\section{Siklus II}

\begin{tabular}{cccc}
\multicolumn{4}{c}{ Pelaksanaan kegiatan belajar } \\
mengajar untuk & siklus II \\
dilaksanakan pada & tanggal & 1
\end{tabular} September 2017 di Kelas IV SD Negeri 167647 kota Tebing Tinggi dengan jumlah siswa 34 siswa. Dalam hal ini peneliti bertindak sebagai guru. Adapun proses belajar mengajar mengacu pada rencana pelajaran dengan memperhatikan revisi pada siklus I, sehingga kesalahan atau kekurangan pada siklus I tidak terulang lagi pada siklus II. Pengamatan (observasi) dilaksanakan bersamaan dengan pelaksanaan belajar mengajar.

Pada akhir proses belajar mengajar siswa diberi tes Ulangan Harian II dengan tujuan untuk mengetahui tingkat keberhasilan siswa dalam proses belajar mengajar yang telah dilakukan setelah dilakukan metode pembelajaran Kooperatif Script. Tes ulangan harian dilakukan untuk melihat peningkatan minat dan prestasi belajar siswa setelah proses belajar mengajar pada siklus II. Instrumen yang digunakan adalah tes ulangan harian II. tampak aspek-aspek yang diamati pada kegiatan belajar mengajar (siklus II) yang dilaksanakan oleh guru dengan menerapkan metode pembelajarn Kooperatif Script mengalami peningkatan dalam penilaian yang cukup baik dari pengamat dibandingkan dengan siklus I sebelumnya. Namun demikian untuk aspek pengelolaan waktu penilaian masih kurang baik. Penilaian tersebut belum merupakan hasil yang optimal, untuk itu ada beberapa aspek yang perlu mendapatkan perhatian untuk penyempurnaan penerapan pembelajaran selanjutnya. Dengan penyempurnaan aspek-aspek diatas dalam penerapan metode pembelajaran Kooperatif Script diharapkan siswa dapat menyimpulkan apa yang telah mereka pelajari dan mengemukakan pendapatnya sehingga mereka akan lebih memahami tentang apa ynag telah mereka lakukan. tampak bahwa aktifitas guru dalam menugaskan siswa memecahkan masalah dalam 
kelompok mendapatkan penilaian yaitu $8 \%$. Jika dibandingkan dengan siklus I, aktivitas lain yang mengalami belum mengalami peningkatan adalah Membimbing dan mengamati siswa dalam menemukan konsep $(6,5 \%)$ dan meminta siswa menyajikan dan mendiskusikan hasil kegiatan (7\%). Sedangkan persentase nilai tertinggi untuk aktivitas siswa pada siklus II adalah mengerjakan tes evaluasi $(15,3 \%)$. Jika dibandingkan dengan siklus I, aktifitas ini mengalami peningkatan. Aktifitas siswa yang mengalami peningkatan yaitu bekerja dengan sesama kelompok $(7,2 \%)$, diskusi antar siswa dan guru (6,5\%), menyajikan hasil pembelajaran (11,5\%), menanggapi/ mengajukan pertanyaan/ide $(10,5 \%)$, dan mengerjakan tes evaluasi $(15,3 \%)$. diperoleh nilai rata-rata prestasi belajar siswa adalah 72,05 dan persentase ketuntasan belajar mencapai $73,52 \%$ atau ada 25 siswa dari 34 siswa sudah tuntas belajar. Hasil ini menunjukkan bahwa pada siklus II ini ketuntasan belajar secara klasikal telah mengalami peningkatan sedikit lebih baik dari siklus I. Adanya peningkatan hasil belajar siswa ini karena siswa-siswa telah mulai terbiasa dengan model pembelajaran Kooperatif Script yang diberikan oleh guru sehingga mereka terbiasa berdiskusi dengan aktif di dalam kelompok mereka masing masing dalam upaya meningkatkan pemahaman mereka terhadap materi yang disampaikan. Saat di kelas, guru juga berusaha meminta setiap anggota kelompok untuk bertanya dan mengemukakan ide mengenai materi pelajaran. Maka dari itu untuk lebih meningkatkan minat dan prestasi belajar siswa dilakukan perbaikan pada siklus berikutnya.

\section{Siklus III}

Pelaksanaan kegiatan belajar mengajar untuk siklus III dilaksanakan pada tanggal 7 September 2017 dengan jumlah siswa 34 siswa. Dalam hal ini peneliti bertindak sebagai guru. Adapun proses belajar mengajar mengacu pada rencana pelajaran dengan memperhatikan revisi pada siklus II, sehingga kesalahan atau kekurangan pada siklus II tidak terulang lagi pada siklus III. Pengamatan (observasi) dilaksanakan bersamaan dengan pelaksanaan belajar mengajar.

Pada akhir proses belajar mengajar siswa diberi tes formatif III dengan tujuan untuk mengetahui tingkat keberhasilan siswa dalam proses belajar mengajar yang telah dilakukan. Instrumen yang digunakan adalah tes formatif III. tampak bahwa aktivitas pada siklus III yang memiliki penilaian persentase tertinggi adalah menugaskan siswa memecahkan masalah dalam kelompok dan memberi umpan balik sebesar (8,5\%), Aktivitas lain yang mengalami peningkatan adalah membimbing dan mengamati siswa dalam menemukan konsep $(7,8 \%)$, menyampaikan langkah-langkah strategi pembelajaran (8\%). Sedangkan untuk aktivitas siswa pada siklus III persentase penilaian tertinggi pada aspek mengerjakan tes evaluasi $(15,7 \%)$, menyajikan $(13,8 \%)$. Aktivitas lain yang mengalami peningkatan adalah bekerja dengan sesama anggota kelompok $(7,8 \%)$ mendengarkan/ memperhatikan penjelasan guru $(4,4 \%)$, merangkum pembelajaran $(4,4 \%)$ dan diskusi antar siswa/antara siswa dengan guru $(7 \%)$. 


\section{Pembahasan}

Diperoleh nilai rata-rata tes ulangan harian sebesar 74,70 dan dari 34 siswa yang telah tuntas sebanyak 29 siswa dan 5 siswa belum mencapai ketuntasan belajar. Maka secara klasikal ketuntasan belajar yang telah tercapai sebesar $85,29 \%$ (termasuk kategori tuntas). Hasil pada siklus III ini mengalami peningkatan lebih baik dari siklus II. Adanya peningkatan hasil belajar pada siklus III ini dipengaruhi oleh semangat siswa yang meningkat dan sudah terbiasa dengan model pembelajaran Kooperatif Script yang disampaikan oleh guru. Saat melaksanakan diskusi dengan pasangannya, siswa sudah mulai aktif melaksanakan kegiatan diskusi dengan baik dan memecahkan masalah terhadap teks materi yang diberikan oleh guru. Sedangkan untuk aktivitas siswa pada siklus III persentase penilaian tertinggi pada aspek mengerjakan tes evaluasi (15,7\%), menyajikan/menanggapi pertanyaan/ide (13,8\%). Aktivitas lain yang mengalami peningkatan adalah bekerja dengan sesama anggota kelompok (7,8\%) pada tahap mendengarkan/memperhatikan penjelasan guru $(4,4 \%)$, merangkum pembelajaran $(4,4 \%)$ dan diskusi antar siswa/antara siswa dengan guru (7\%). Presentase pengelolaan pembelajaran pada siklus III adalah sebesar 85,29\%. Hasil ini sudah melebihi indikator yang ditentukan pada penelitian ini.

\section{SIMPULAN}

Dari hasil kegiatan pembelajaran yang telah dilakukan dapat disimpulkan bahwa penerapan metode pembelajaran Kooperatif
Script memiliki dampak positif dalam meningkatkan minat dan prestasi belajar siswa pada mata pelajaran bahasa Indonesia di Kelas IV SD Negeri 167647 kota Tebing Tinggi yang ditandai dengan peningkatan ketuntasan belajar siswa pada setiap siklusnya. Penerapan metode Kooperatif Script membuat siswa yang lebih aktif, mempertanggungjawabkan tugas serta menyampaikan gagasan berita/cerita mengenai materi pelajaran bahasa Indonesia yang diajarkan guru secara individu maupun kelompok.

\section{DAFTAR RUJUKAN}

A'la, Miftahul. 2011. Quantum Teaching. Yogyakarta: Diva Press.

Dalyono, M. 2000. Psikologi Pengajaran. Jakarta : PT. Rieneke Cipta.

Djamarah, S. B. 2002. Rahasia Sukses Belajar. Jakarta: PT. Rineka cipta

Fajar, A. 2005. Portofolio dalam Pembelajaran IPS. Bandung: Remaja Rosda Karya

Hamdani. 2011. Strategi Belajar Mengajar. Bandung: Pustaka Setia.

Hadi, S. 2007. Pengaruh startegi pembelajaran Kooperatif Script terhadap keterampilan berpikir kritis, keterampilan meta kognitif, dan kemampuan kognitif biologi pada siswa SMA Laboratorium.

Isjono. 2009. Cooperative Learning. Bandung: Alfabeta 
Benny Hutapea: Meningkatkan Hasil Belajar ...

Isnawati, Y. 2011. Peningkatan

Kemampuan Menyimak Berita

Melalui Model Pembelajaran

Kooperatif Script Pada Si Swa

Kelas VII SD N 4 Purworejo

Tahun Pembelajaran 2012/

2013. Purworejo.

Kunandar. 2008. Langkah Mudah

Penelitian Tindakan Kelas.

Jakarta: PT. Raja Grafindo

Persada.

Nuryanti, B. L. 2009. 99 Model

Pembelajaran. Bandung: Bina

Tugas Mandiri

Slameto. 2010. Belajar dan Faktor-

Faktor yang

Mempengaruhinya. Jakarta:

Rieneke Cipta

Sudjana, N. 2006. Penilaian Hasil

Proses Belajar Mengajar.

Bandung : PT. Remaja Rosda

Karya 